\title{
Towards true product sustainability
}

\author{
Thomas Dyllick, Zoe Rost \\ Institute for Economy and the Environment (IWÖ-HSG) \\ University of St.Gallen
}

\begin{abstract}
Product sustainability is usually looked at from a business perspective with the goal to reduce product related risks or to differentiate the product from those of the competition - mostly with limited effects for sustainable development (SD). In light of the global sustainability challenges, we raise the question how products can make a significant contribution to SD? In addressing this question we analyze the evolution of the concept of product sustainability over time. This analysis is guided by two questions and it applies two different perspectives. The first question uses an analytical perspective and asks: "How have different product sustainability concepts been framed with regard to their contributions to SD and how have they evolved over time?" The second question uses a normative perspective and asks: "How do the product sustainability concepts in their different developmental phases contribute to SD?" We present a systematic analysis of the evolving perspectives of product sustainability which we group in three different phases and levels of development: from selective to holistic improvements (Product Sustainability 1.0), from better products to good products (Product Sustainability 2), and from private value to public value generation (Product Sustainability 3.0). In this evolution we perceive a development towards a model of "true product sustainability", where the product makes a specific contribution to solving societal problems.
\end{abstract}

\section{Introduction}

Product sustainability (PS) looks at how products can provide economic benefits to companies while at the same time providing environmental and social benefits to society in general. Or, in other words, PS aims at balancing the contributions of products to the triple bottom-line, thereby creating multiple and shared values for different stakeholders. There have been a great number of different approaches of how this balance can be achieved and preserved through eco design, design for sustainability, cradle-to-cradle, product service systems or handprinting. While early approaches were focusing on balancing economic and environmental benefits, the discussion later moved on to address sustainability problems in all its dimensions. And while the discussions revolved for long around minimizing the negative impacts of products, more recent approaches have started to focus on positive impacts, thereby aiming for net-positive products. The evolution of these different approaches to PS presents a remarkable development that is rarely perceived. 
From a business perspective PS serves to keep companies competitive in times of changing consumer and public demands, asking for an improved sustainability performance of the products offered (e.g. Nielsen Company, 2015). It may either help companies to prevent or reduce product related risks, or it may help to differentiate the products from those of their competitors. From a societal perspective PS is seen to contribute to sustainable development, by reducing the ecological footprint or by improving the social condition. Sustainable production and consumption has been on the global political agenda since the first "Earth Summit" 1992 in Rio de Janeiro, and it figures prominently as a Sustainable Development Goal in the U.N. “Agenda 2030” (U.N. General Assembly, 2015, Goal 12: “Ensure sustainable consumption and production patterns"). However, finding the right balance between private benefits and public values remains a continuous challenge. This becomes even more dynamic with political and standard setting bodies (e.g. EU, ISO) intervening to adapt the economic rules of the game.

While the business success of PS can be measured easily by looking at economic success indicators like sales, market share or customer satisfaction of sustainable products, its sustainability contribution remains vague at best. From a business perspective any sustainability improvement relative to the previous product or compared to the prevailing products on the market may be seen as satisfactory, because the new product displays an improved sustainability performance. From a sustainability perspective this is not so simple, as there are many different dimensions and degrees of sustainability improvements involved. In looking at the product sustainability literature we quickly realize there are many types of sustainability improvements and many shades of green or sustainable products. And as time goes on, the number of different approaches seems to be increasing. It is not just the ecoefficiency or the socio-efficiency of a product that is in question, but its aggregate contribution, and it is not just the production phase which is of relevance, but the whole product life-cycle. And the companies are not only asked to reduce the product footprint, but to contribute to the betterment of the world. Which result is "better" or "more sustainable" very often is a challenging question that is difficult to answer. Also, it is not clear at all, what "better" or "more sustainable" means in the first place, because there usually are very different meanings of the terms involved. Consequently, the contributions of PS to sustainable development (SD) remain a challenging question.

This paper is innovative in its goal to clarify and understand the development of PS concepts over time and in its interest to develop a path towards higher and more ambitious levels of sustainability, towards "true product sustainability". Its ambition thereby is mainly conceptual by developing a PS typology. It applies a sustainability perspective to analyze and characterize the evolution of PS concepts over time. It is thereby guided by two connected, but different questions and it applies two different perspectives, an analytical and a normative perspective. 
1. The first question uses an analytical perspective and asks: "How have different PS concepts been framed with regard to their SD contributions and how have they evolved over time?" More precisely, we ask: What do these concepts look like? What is their particular sustainability focus? And how does this focus change over time? In looking at the different concepts, we will analyze and evaluate their SD contributions and we will come up with a model of the successive phases in the development of PS concepts.

2. The second question uses a normative perspective and asks: "How do the PS concepts in their different developmental phases contribute to SD?" In particular, we ask: How can the PS concepts increase their contribution to SD? And what does a model of "True Product Sustainability" look like?

In answering these questions, we will suggest a product sustainability typology, with three different levels of development appearing over time: Product Sustainability 1.0, 2.0 and 3.0 whereby the higher levels incorporate the lower levels (Figure 1).

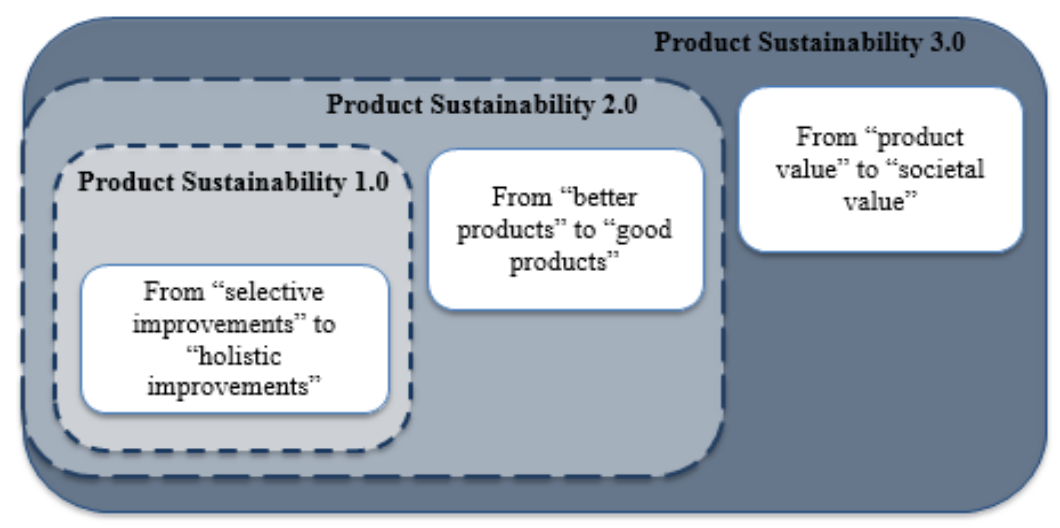

Figure 1: Product Sustainability Typology

PS concepts on the level of Product Sustainability 1.0 will be characterized by developments that move from selective improvements to holistic improvements of products, thereby going beyond specific improvements of products. PS concepts on the level of Product Sustainability 2.0 will be characterized by developments from "better products" to "good products". Better products are defined in a relative way, typically by comparing them to existing products or alternative solutions on the market. Good products, however, are defined by comparing them to some absolute measure or given standard of sustainability performance. PS concepts on the level of Sustainability 3.0 will be characterized by developments from product value to societal value. On this highest level it is not sufficient any more to contribute to a sustainable product, but to contribute to a sustainable world. Effective approaches to PS, which will be classified as "True Product Sustainability", are expected to make relevant contributions to SD problems and address the "big disconnect" between micro-level improvements and macro-level deterioration, as suggested by Dyllick and Muff (2016) in their approach to develop a typology for business sustainability. 
The paper is based on a broad literature analysis of contributions to PS. The analysis, however, is done with a specific focus on the evolution of different and more ambitious PS concepts. The level of ambition is defined with regard to their SD contribution. In this paper we will first clarify the background of our analysis by looking at the SD challenges and how the reactions have been framed in the sustainability management and innovation literature (section 2). Then we will analyze the evolving perspectives of PS and group them into three different phases of development (section 3). In a final section we will summarize our analysis in an overarching model of PS evolution "towards true product sustainability" and present our conclusions (section 4).

\section{Background: The challenges of sustainable development}

The sustainability contributions of products have mostly been neglected compared to their competitive contributions, although their relevance for sustainable development is undisputed. In this background section, we will briefly characterize the challenges of SD and ask for the contributions of the fields of sustainability management and sustainability-oriented innovation to overcome the "big disconnect" between micro-level improvements and macro-level deterioration. In particular, we will look at the approaches and typologies developed by Dyllick and Muff (2016) for business sustainability and Adams et al. (2016) for sustainability-oriented innovation as models for developing a typology for true product sustainability.

\subsection{Sustainable development and the search for a just and safe space for humanity}

Humanity is living far beyond the planet's means, consuming the Earth's renewable resources as if we had more than one planet to draw upon. According to the estimation of humanity's global footprint we are using the resources of more than one and a half planets (WWF, 2016). At the same time, there are significant disparities between regions and their footprints. If we all consumed at the level of the European consumers, we would need the resources of three planets; at the level of the US consumers, we would need more than four planets. An absurd thought that becomes scary when we consider the projections for the global middle class tripling to reach 4.9 billion by 2030 with an additional 2.7 billion middle-class consumers in Asia alone (WEF \& Accenture, 2012). These will increase our global footprint to reach a bio-capacity need of 2 planets by 2030. According to the results of the UN Millennium Ecosystem Assessment, one of the largest assessment of the health of ecosystems ever undertaken, $60 \%$ of our collective "ecosystem services" have been degraded over the last 50 years, thereby reducing its value for future generations (MEA, 2005). And an international group of earth system scientists led by Johan Rockstrom concludes that we have already passed 4 of the 9 crucial planetary boundaries (biodiversity, nitrogen and phosphorous cycles, land-use change, climate change) which allow us to live a sustained and safe life, while 2 more are approaching their limits (Rockstrom et al., 2009; Steffen et al., 2015). 
A vision of SD has to include also the importance of societal well-being as an integral part of our planetary well-being. Eradicating poverty and achieving social justice is inextricably linked to ensuring ecological stability and renewal. While planetary boundaries provide an environmental ceiling defined by critical natural thresholds, there are also social boundaries defined by critical human deprivations. They represent a kind of lower limits and provide a minimal social foundation for SD. Raworth (2012) developed a helpful "doughnut model" or "life-safer model” with an outer environmental boundary and an inner social boundary. Between a minimal social foundation that protects against critical human deprivations and an environmental ceiling that avoids critical planetary thresholds lies a "safe and just space for humanity" to thrive in. In response to the global challenges the U.N. General Assembly (2015) accepted in the fall of 2015 the Sustainable Development Goals (SDGs) as their new "Agenda 2030" to guide the global community on their sustainable development journey and to keep them in their safe and just space.

\subsection{Sustainability management: From refined shareholder value management to true business sustainability}

The role of business in making our world a more sustainable place is at the center of the study of sustainability management. If we follow the studies monitoring the acceptance and integration of sustainability by big companies, there is a strong consensus emerging that sustainability is having and will continue to have a significant material impact on company strategies and operations. More and more business executives agree that sustainability-related strategies are necessary to be competitive today and even more so in the future. They report that benefits of addressing sustainability accrue not only to the environment and to society, but also to the companies themselves, through tangible benefits in the form of reduced costs and risks of doing business, as well as through intangible benefits in the form of increased brand reputation, increased attractiveness to talent and increased competiveness (Bové, Bonini, 2014; Kiron et al., 2013; UN Global Compact, Accenture, 2013 and 2010; Haanaes et al., 2012; Haanaes et al., 2011).

But somehow this good news is not reflected in studies monitoring the state of our planet and our societies. What results from this discrepancy between micro level progress and macro level deterioration is a "big disconnect" between company activities and the global state of the environment and society. Dyllick and Muff (2016) present three reasons in their analysis: First, the academic business sustainability (BST) discussion is at a very early stage with crucial elements - a standardized definition, scope, focus, underlying theoretical approaches and measures - still very diverse and highly debated (Montiel, Delgado-Ceballos, 2014). Second, the BST discourse is located on the micro-level of organizations, while most of the SD discussions take place on a macro-level. What is needed are 
approaches that effectively link both levels (Whiteman, Walker, Perego, 2013). Third, while the SD discourse concentrated on reaching the global SD goals with performance measures addressing the degree of the SD goals being effectively reached, the BST discourse has focused on business value (win-win strategies). Different concepts have been suggested and used over time. The BST discussion centered first on eco-efficiency as a performance measure, thereby drawing a positive link between environmental improvement of processes and products and bottom line benefits (e.g. DeSimone, Popoff, 2000). More recently, the BST discussion has been concentrating on defining a business case for corporations which can take on very different forms, e.g. risk reduction, cost efficiency, reputational effects, market differentiation or market development (e.g. Dyllick, Hockerts, 2002; Steger, 2006; Schaltegger, Wagner, 2006). While the business case addresses a strategic level, ecoefficiency addresses a more operational level. What is common to both concepts is that BST is clearly focused on creating business value through sustainability management, while the contribution to achieving SD goals remains very vague at best. This applies also to the most recent mutation of business value, the concept of shared value creation, which promises to bridge business value and societal value (Porter, Kramer, 2011). It may be concluded here that BST improvements cannot and will not contribute in any significant degree to improving the global situation as long as the two levels of BST and SD are disconnected and, even more importantly, as long as the performance measures used lead into very different directions.

If we look at how the concept of business sustainability today is interpreted in theory and practice, it appears that the current concepts are strongly aligned with economic advantages for business, but much less with solutions for the sustainability challenges we are facing. So we should not really be surprised, if company contributions to solving sustainability issues remain globally invisible. To overcome this disconnect, Dyllick and Muff (2016) reviewed the established approaches to BST and developed a typology that focuses on effective business contributions to sustainable development. Their typology for BST ranges from Business Sustainability 1.0 to Business Sustainability 2.0 and to Business Sustainability 3.0. What do they mean by this?

In a first phase of a developing concept of business sustainability, companies are confronted with social and ecological concerns from outside their markets which put them under pressure to act. However, economic objectives remain a priority for the company. Companies recognize that through sustainability management they can save costs and reduce risks, they can increase their reputation on the job market as well as their differentiation in the product markets. A definition from SAM and PWC (2006) spells out this early understanding: "Corporate sustainability is an approach to business that creates shareholder value by embracing opportunities and managing risks deriving from economic, environmental and social developments." Dyllick and Muff define this early form of "Business Sustainability 1.0" as a form of "refined shareholder value-management". 
In a second phase sustainability is being increasingly institutionalized inside the company. Companies start broadening their stakeholder perspective and pursuing a triple bottom line approach. Value creation goes beyond shareholder value and includes social and environmental values. This advanced view of "Business Sustainability 2.0" is well captured in the definition used by the Network for Business Sustainability (2012): "Business sustainability is often defined as managing the triple bottom line - a process by which firms manage their financial, social and environmental risks, obligations and opportunities. These three impacts are sometimes referred to as people, planet and profits" which combination of impacts Dyllick and Muff (2016) call "Managing for the Triple Bottom Line". In contrast to BST 1.0 not only economic objectives, but also social and ecological objectives are pursued by business. But the companies still look at things from the inside out, from its own activities to society and the world. And it is all about diminishing the negative side effects of the economic activities, about reducing the ecological and social "footprint" of the company. Only a minority of the companies pursuing sustainability management can be found on this more advanced level.

The third phase requires two different things, a shift from "Inside-Out-Thinking" to "Outside-InThinking", i.e. when the company starts from society and its problems and then asks itself which opportunities arise by contributing to solving societal challenges? But also a shift from a focus on reducing negative impacts to making a positive contribution. As a result "Business Sustainability 3.0" is defined by Dyllick and Muff (2016) as follows: "Truly sustainable business shifts its perspective from seeking to minimize its negative impacts to understanding how it can create a significant positive impact in critical and relevant areas for society and the planet." Only very few companies, mostly social businesses, can be found in this category. They conclude, that only when sustainability objectives and strategies of business are reconnected to the sustainability challenges we are collectively facing, can we hope that they will effectively contribute to resolving them. This, they call "true business sustainability". As long as this is not the case, BST may continue to be good for business, but it will not contribute significantly to solving society's challenges in the sustainability field.

\subsection{Sustainability-oriented innovation: From operational optimization to systems building}

For companies to contribute to sustainability, innovation plays an important role (Hansen et al., 2009; Schaltegger, Wagner, 2011). For Mohrmann and Worley (2010) sustainability is not a question of either/or, rather it is a journey, a process of becoming more sustainable. Klewitz and Hansen (2014) suggest the term "sustainability-oriented innovation" (SOI), as they think of it as a deliberately managed process toward sustainability. Recent reviews of SOI conclude that very little attention has 
been paid to the SOI topic and what exists is often found to be deficient (Klewitz, Hansen 2014; Doherty et al. 2014; Adams et al., 2016; Boons et al., 2013): In particular, it remains unclear what sustainability means and how it can be achieved; most work tends to treat sustainability dichotomously, rather than interpreting it as a process or a journey; and the debate has been focused on eco-innovations thereby overlooking the social dimension.

With regard to small and medium sized enterprises (SME) Klewitz and Hansen (2014) identified in their review of the recent literature (1987 - 2010) SOI innovation practices in three different areas: process innovations (cleaner production, waste-handling, eco-efficiency, logistics), organizational innovations (environmental management systems, supply chain management, local sourcing and production, health and safety, redesign of the company's innovation process) and product innovations (eco-design, design for sustainability, life-cycle analysis, (eco) labeling, fair-trade and organic products). In most cases they found an interaction between all three areas. In which way these innovations were implemented, depended on the SMEs' sustainability strategies. They found five different strategies: resistant SMEs, reactive SMEs, anticipatory SMEs, innovation-based SMEs, and sustainability-rooted SMEs. These strategies move from incremental strategies to more radical, inclusive, and integrative strategies.

In another broad literature review covering the period 1992-2012 and including not only scientific literature, but also grey literature and the blogosphere to address the problems of time lag, to provide more contemporary, relevant and contextually important findings as well as "the wisdom of practice", Adams et al. (2016) developed a much broader and complex model of SOI. For them SOI is defined as involving “intentional changes to an organization's philosophy and values, as well as to its products, processes or practices to serve the specific purpose of creating and realizing social and environmental value in addition to economic returns" (Adams et al., 2016). They distilled three distinct SOI approaches from the literature with companies moving to higher and more ambitious levels as they progress on their sustainability journey. They thereby shift from being internally oriented, incremental and efficiency-focused to being more radical and systemic. On a first level, called "operational optimization", companies focus on "doing the same things better". They comply with changing regulations or pursue efficiency gains while they focus on mostly internal and incremental innovations. The innovation outcome is a reduction of harm. On a second level, which they call "organizational transformation", companies focus on "doing good by doing new things". They develop new products, services or business models, which may include a shift in company purpose. The innovation outcome moves from reduction of harm to creating shared values with societal stakeholders. On a third level, called "systems building", companies focus on "doing good by doing new things with others" whereby they start thinking beyond the firm and reframe the purpose of business in society. They develop product offerings they could not achieve by themselves, but require 
collaboration and partnerships with diverse stakeholders. The innovation outcome is to create a net positive impact. In placing the companies represented in their research in their SOI model, they found $70 \%$ to be on the first level, $28 \%$ on the second level and $2 \%$ represented a combination. None of the studies included in their review provided evidence of companies having reached the third level, which remains aspirational (Adams et al., 2012).

\section{Evolving perspectives of product sustainability}

The understanding of PS varies widely in the literature and it clearly evolves over time. We will structure the discussion of model evolution into three different phases (and levels), the dominant model of product life-cycle optimization, a new model of good products instead of better products, and a still quite visionary emerging model with a focus on social value generation. Only this last model qualifies as "true product sustainability", which allows for effective contributions to solving sustainability problems.

\subsection{The dominant model of product sustainability: Eco-Design}

The model of PS most often referred to in theory and - in particular - in practice refers to the idea of a "green product", which optimizes the product's eco-efficiency over the whole product life cycle by use of "eco-design" or "design for environment". It has been integrated into different ISO standards (ISO 14040, 14006, 14001) where it is referred to as "cradle-to-grave product life cycle perspective". Its focus is exclusively on the environmental dimension of sustainability.

Research and practice agree on the need to consider the entire product life cycle in order to evaluate a product's sustainability impact. In contrast to approaches focusing on single phases of the product life cycle like cleaner production, green purchasing or green logistics, life cycle thinking takes all lifecycle phases into account. Its goal is to avoid trade-offs and burden shifting between life cycle phases, but also to help define priorities for effective action (Okongwu et al., 2013; Linton et al., 2007; Fiksel et al., 1998). A life cycle perspective typically spans all phases from raw material extraction to end-oflife treatment and final disposal (Figure 2). It thereby follows the product along its material life cycle, "from cradle to grave". A product is considered to be "green" or "sustainable" when the aggregate environmental burden is lower than the one of competitive products or previous product editions. 


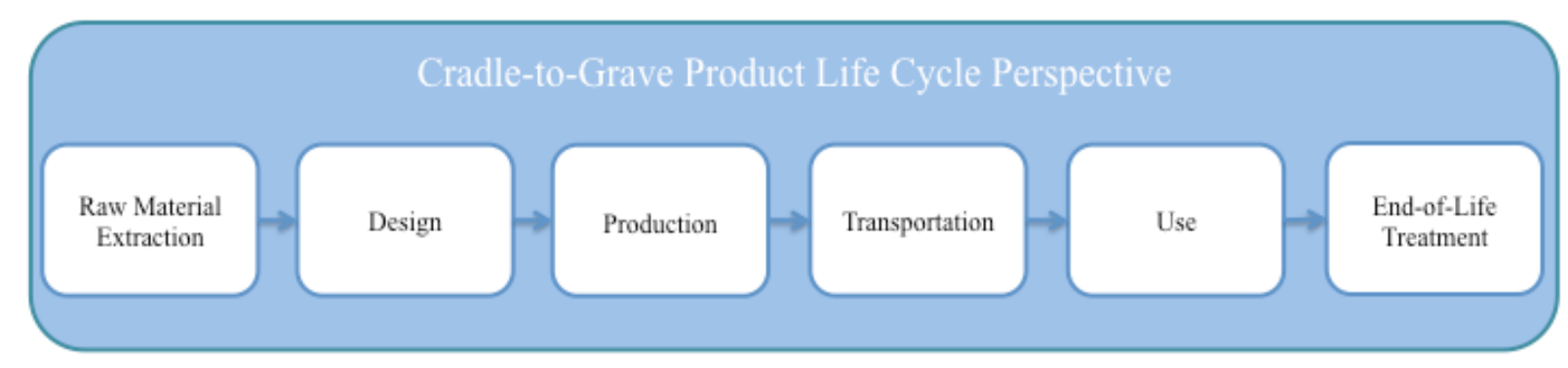

Figure 2: Cradle-to-Grave Product Life Cycle Perspective (ISO 14040)

Many definitions of a "green" or "sustainable product" directly or indirectly refer to the life cycle perspective. Peattie (1995) calls a product "green" when its environmental performance surpasses competitive products in production, use and disposal (Peattie, 1995; Belz and Peattie, 2012). Ottman et al. (2006) state that "although no consumer product has a zero impact on the environment, in business, the terms 'green products' or 'environmental product' are used commonly to describe those that strive to protect or enhance the natural environment by conserving energy and/or resources and reducing or eliminating use of toxic agents, pollution, and waste". According to the WBCSD (2008), sustainable products deliver high functional and emotional value, while minimizing resource use and environmental impact. The definition of sustainable production and consumption used by the United Nations in the context of their Agenda 2030 (Sustainable Development Goals) goes back to 1994 and defines sustainable production and consumption similarly as "The use of goods and services that respond to basic needs and bring a better quality of life, while minimizing the use of natural resources, toxic materials and emissions of waste and pollutants over the life cycle, so as not to jeopardize the needs of future generations" (UN SDKP).

The life cycle perspective has become the foundation of a multitude of concepts and tools for managing product sustainability (Valdivia et al., 2013; Zamagni et al., 2013). Most of these tools help to assess the current state of a product and provide orientation for its improvement. Examples include the "Product Carbon Footprint" and the "Product Water Footprint". They allow a quantitative assessment of environmental burdens caused by a product along its life cycle, focusing on one or more critical indicators (e.g. $\mathrm{CO}_{2}$ emissions, water usage). The key instrument for product life cycle management, however, is the environmental Life Cycle Assessment (eLCA). The eLCA summarizes, visualizes, quantifies and interprets impacts of a product's production, processing, use and recycling phases on the environment. An eLCA includes the use of resources, water, and energy in the same way as it considers greenhouse gas emissions, the pollution of soil and water, or generated waste (Rebitzer et al., 2004). Thereby it is more holistic than footprint calculations which typically focus on singular indicators. Due to significant issues related to definitions of system boundaries and impact calculations, the International Organization for Standardization (ISO) has released a formal guide for performing life cycle assessments. ISO 14040 defines a life cycle as "consecutive and interlinked stages of a product system, from raw material acquisition or generation from natural resources to final disposal" (ISO 14040, 2006). According to ISO 14040, all goods and services have an impact on the environment, which can occur at 
any or all life cycle phases, while impacts can be manifold, slight or significant, short-term and longterm, and may occur at a local, regional, and/or global level.

The eLCA is often used as an eco-design tool. Eco-Design (also called "Design for Environment") has been defined in an ISO guide as "the integration of environmental aspects into product design and development, with the aim of reducing adverse environmental impacts throughout a product's life cycle" (ISO 14006). Eco-design tools are primarily used in the product design phase where $80-90 \%$ of environmental burdens caused by the product are determined (Fabrycky and Blanchard, 1991; Gattenby and Foo, 1990). The goals of eco-design are durability, material efficiency, energy efficiency, the restriction of problematic materials, efficiency in use, recyclability, or reparability. It thereby helps to meet the consumer's requirements, but in a more sustainable way (Crul and Diehl, 2009). However, similar to life cycle assessments, it exclusively focuses on improving the environmental performance of a product by minimizing its negative impacts.

Product life cycle thinking meanwhile has made its way into standard setting and policy development. ISO standard 14020 on eco-labelling has been developed to avoid banal, untrustworthy and incomprehensible product claims in order to guide end customers towards environmentally friendly product choices. ISO 14020 thereby requires the consideration of the entire product life cycle. More recently, the European Commission (2013) has launched the Product Environmental Footprint (PEF) method as part of its "Single Market for Green Products Initiative", aiming for a common way of measuring environmental performance across the different European countries. The PEF is a multicriteria environmental measure of a good or service throughout its life cycle that allows companies to demonstrate the environmental performance of their products or services to customers and the public in a more trustful way. The approach was tested between 2013-2016 together with more than 280 volunteering companies and organizations to understand the real potential of the method before proposing new policies.

Life cycle thinking and assessments have contributed to a stronger focus on product sustainability, by providing accepted concepts and tools for managing products. The extension across the entire life cycle, including all upstream and downstream processes, is a fundamental component of truly sustainable products. It helps to avoid trade-offs and burden shifting between different life cycle phases. Life cycle thinking is also systems thinking. It does not only include the product itself but also its links to and its impacts on the product's context. Systems thinking helps to avoid sub-optimizations and rebound effects. As a holistic concept, life cycle assessments look at multiple environmental dimensions. They provide transparent assessments of all environmental burdens along the product life cycle and allow for specific actions to reduce negative impacts on the environment (UNEP and SETAC, 2007). eLCA is particularly valuable in identifying and addressing the most material sustainability challenges along the product life cycle.

However, life cycle thinking has also its limitations. Its focus on environmental aspects neglects the economic and social dimension of sustainability. According to Edwards (2009) a product sustainability assessment also needs to include the people who are related to the production of the product, those who use it, and those who deal with it at the end of its life. Communities and ecosystems need to be 
considered, which are affected by the product through manufacturing, use, and disposal. Furthermore, the aim of life cycle thinking is to make the existing product more sustainable compared to its current state or competitor products. This approach locks product improvements into a cage of incremental improvements. However, a truly sustainable product cannot be restricted to being more efficient or less harmful than the given alternative. Resources will continue to be depleted and problems will further increase. And finally improvements based on eLCA do not question the product itself, but only the environmental performance along its life cycle. The product, even if it is environmentally or ethically questionable, could still be presented as a (more) sustainable product. Obviously a different approach is needed to move towards "true" product sustainability.

\subsection{Completing the dominant model of product sustainability: Design for Sustainability, Cradle-to-Cradle, Product-Service Systems}

Later and more advanced approaches have built on the achievements and limitations of eLCA in order to move the discussion ahead towards truly sustainable products. Here we will take a look at three such concepts that can be seen as completing the dominant model of product sustainability: design for sustainability, cradle-to-cradle, and product-service systems.

\section{Design for Sustainability}

Since Elkington launched the idea of the triple bottom line in 1997, it has become widely accepted that sustainability comprises three dimensions: an environmental, economic, and a social dimension. In order to overcome the limitations of the purely environmental focus of eco-design and eLCA, newer concepts have been developed that take all pillars of the triple bottom line into account. They maintain the life cycle perspective but expand the focus to include economic and societal aspects. They are generally subsumed under the term "Design for Sustainability" (D4S) and highlight the need to consider sustainability aspects in the product design phase.

D4S aims to enable product designers and developers to take sustainability into account in their daily work. According to Fargnoli et al. (2014) D4S is the most widespread design approach for companies to respond to ecological and social expectations while still fulfilling customer needs in new product development. UNEP and the University of Delft developed a guide for D4S, where it is called "an evolution from eco-design" (Crul et al., 2009). D4S can be applied both to redesign existing products or to new product development. And it can be used for incremental or radical innovations. Its authors argue that radical innovation is needed in order to reach true sustainability. In implementing D4S, the established ecological focus is often supplemented by a social and economic component. Thereby the eLCA is complemented by social life cycle assessment (sLCA) and life cycle costing (LCC). The sLCA focuses on social aspects of a product and its upstream and downstream processes and includes the product utility and social acceptability of products. Together with the economic evaluation through LCC, eLCA and sLCA can be combined to a comprehensive Life Cycle Sustainability Assessment (LCSA) that considers all three dimensions of sustainability (Valdivia et al., 2013). LCSA reveal tradeoffs as well as trade-ons between different sustainability dimensions, life cycle phases and impacts. 
Thereby, the LCSA aims at reducing a product's negative footprint while simultaneously improving its socio-economic performance throughout its life cycle (UNEP and SETAC, 2007).

However, the practical application of a comprehensive D4S strategy and LCSA are still disappointing. Companies typically cherry-pick the focus on ecological or social issues, while the idea of a synergetic assessment is poorly received in practice (Fargnoli et al., 2014). But also on a conceptual level, D4S falls short of what would be needed as it is still based on achieving relative improvements compared to a given baseline. The focus is on producing "better" products. Crul \& Diehl (2009) criticize that D4S redesign approaches often result in incremental changes, although radical innovations are required to achieve factor 10-20 improvements. In their opinion, the redesign of existing products may even limit sustainability gains that companies could achieve with the development of entirely new solutions. Also, the sLCA typically has a rather narrow focus mainly on human rights, health and safety, wages, and inadequately addresses the social impacts of products on consumers (Parent et al., 2012). Zamagni et al. (2013) conclude more broadly: „LCSA (...) will need to expand its goal beyond targeting hotspots and minimizing negative impacts to developing positive solutions and encouraging social learning and adaptation, and accept the inherent uncertainty and ignorance that characterizes any sustainability assessment.“

\section{Cradle-to-Cradle}

While D4S adds the missing sustainability dimensions to the LCA, Cradle-to-Cradle $(\mathrm{C} 2 \mathrm{C})$ aims for reducing the negative environmental impacts by closing the product loop. Traditionally the product life cycle is seen as a linear process, reaching from raw material extraction to end of life treatment and disposal, with resource consumptions, emissions and waste at each stage. McDonough \& Braungart introduced in 2002 the $\mathrm{C} 2 \mathrm{C}$ concept, where products are reused or remanufactured at the end of their lives. While the classical life cycle assessment adapts a "cradle to grave" perspective, "cradle to cradle" tries to establish a continuous cycle of outputs and inputs. The authors distinguish between a biological cycle and a technical cycle (Figure 3). 


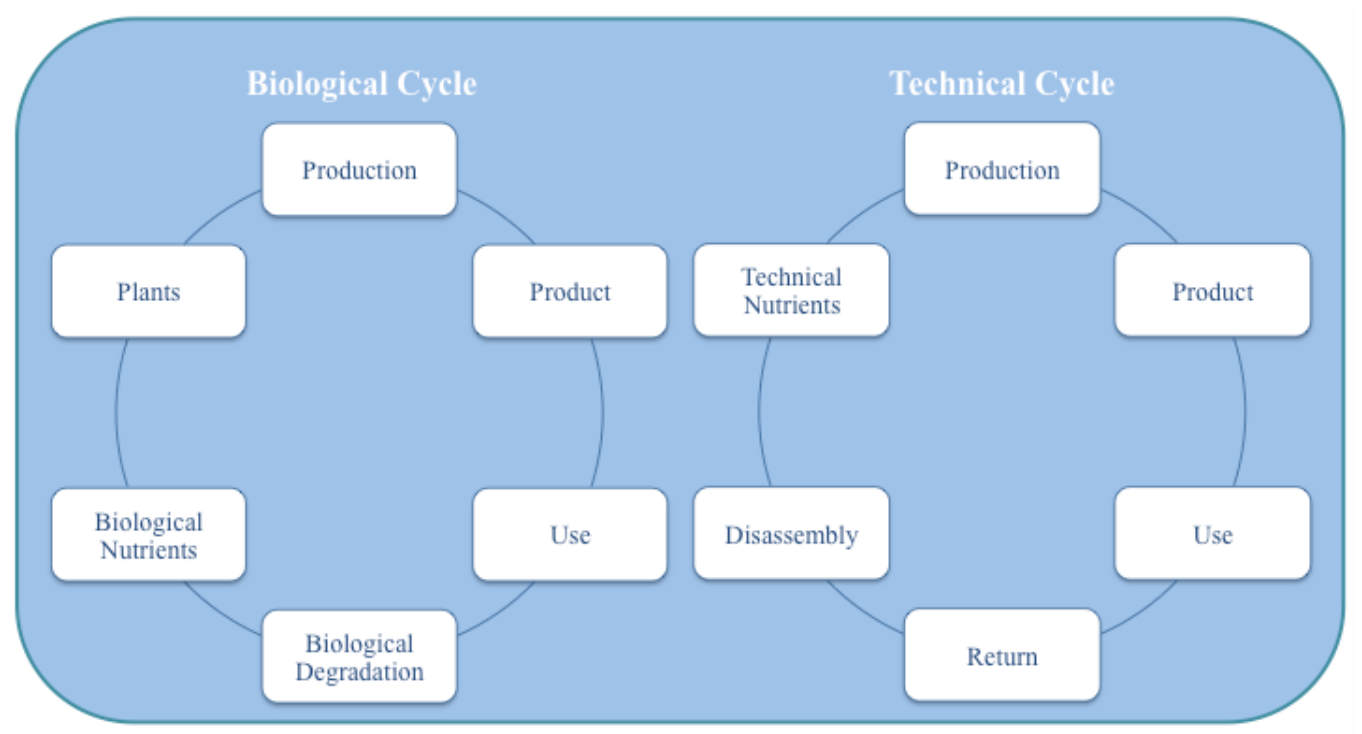

Figure 3: Cradle-to-Cradle Product Life Cycle Perspective

The Cradle-to-Cradle concept is based on natural (nutrient) flows and cycles. The idea originated from biological metabolism, were waste of one natural process is used as nutrient or energy by another organism or system. Transferred to products, the result is a closed-loop system that eliminates the concept of waste. With regard to biological inputs (e.g. textiles, paper, woods) products should be designed and produced in a way that they can be naturally degraded and used as nutrients without negative impacts on the environment. With regard to technical inputs (e.g. metals, plastics), products should be designed and produced in a way that makes disassembly and re-use possible without adverse effects on the environment. (McDonough and Braungart, 2002)

$\mathrm{C} 2 \mathrm{C}$ is based on a set of core principles and it offers a standard for product certification. The three core principles cover the elimination of the concept of waste, the exclusive usage of renewable energy and the celebration of diversity (Cradle to Cradle Products Innovation Institute, 2013). These core principles are operationalized in five dimensions for the certification scheme: material health, material reutilization, renewable energy \& carbon management, water stewardship, and social fairness (MBDC, 2013). Material health focuses on safe chemistry, and ingredients that can be safely used in continuous cycles. Material reutilization focuses on recovering used products and continuously reuse materials. Approaches might include design for disassembly and the education of customers. According to the third dimension, all operations should be exclusively powered by renewable energies. Producers should furthermore strive to improve energy efficiency along the product life cycle and reduce the total amount of energy usage. Companies should further protect and enhance water quality in production processes and commit to water stewardship, e.g. taking into account local impacts of water usage. The social sustainability pillar is represented by the dimension "social fairness", which includes health and safety, ethical business behavior, and dialogue with internal and external stakeholders. For all dimensions, producers should establish a continuous improvement process. In addition to these five dimensions, the $\mathrm{C} 2 \mathrm{C}$ standard excludes certain products on ethical grounds, e.g. weapons, tobacco, and nuclear power (Cradle to Cradle Products Innovation Institute, 2013). It is an indication that also the product purpose and related risks need to be considered when assessing the sustainability of a product. 
$\mathrm{C} 2 \mathrm{C}$ thinking has inspired far reaching initiatives around models of a circular economy, where products and materials are kept in a closed loop. Instead of the current "take-make-dispose" logic of the dominant production and consumption system, circular business models aim at optimizing products for continuous cycles of disassembly and reuse or biodegradability. Circular design thereby focuses on material selection, modularisation, and design for easier disassembly (Ellen MacArthur Foundation, McKinsey and WEF, 2014). In December 2015 the EU Commission published its "Circular Economy Package" aiming for far reaching changes in the economy: "The proposed actions will contribute to "closing the loop" of product lifecycles through greater recycling and re-use, and bring benefits for both the environment and the economy. The plans will extract the maximum value and use from all raw materials, products and waste, fostering energy savings and reducing Green House Gas emissions. The proposals cover the full lifecycle: from production and consumption to waste management and the market for secondary raw materials" (EU Commission, 2015).

$\mathrm{C} 2 \mathrm{C}$ is a far-reaching and in many ways a very inspiring concept, but it also has its limitations. It tackles toxic materials and problems like waste or the degradation of non-renewable resources, while other issues are ignored, particularly related to the social dimension. Although some social indicators are included in the standard, they are very selective. Neither problems of developing countries are taken into account, nor are there inspirations how products and production processes may contribute to social equity and justice. $\mathrm{C} 2 \mathrm{C}$ overall focuses on environmental issues and - despite some more progressive ambitions to move beyond a focus on "less bad" and aim for "more good" solutions - it concentrates primarily on reducing harmful impacts. It is about continuously phasing out hazardous chemicals or reducing the amount of water used in production processes. Examples of positive impacts, like the increase in renewable energy, is not really more than the reduction of greenhouse gas emissions. Real potential for positive contributions can mostly be found in the social dimension (Cradle to Cradle Products Innovation Institute, 2013). Also, C2C strongly focuses on the final product and in-house production processes, while mainly implicitly considering upstream and downstream processes. Particularly the use phase receives little attention although that is where many products are particularly challenged. Due to the final objective of eliminating all environmental burdens related to products and production processes, $\mathrm{C} 2 \mathrm{C}$ is actually pro consumption and supports increased production. As the ultimate goal is the endless recycling and reuse of products, cradle-to-cradle actually proclaims that no consumption cutting is required, customers must not rethink their consumption patterns, and industry must not move away from the idea of limitless growth. Unfortunately, the concept is rarely fully implemented. Often companies consider only single categories, which lowers $\mathrm{C} 2 \mathrm{C}$ to the level of footprint reductions. Furthermore $\mathrm{C} 2 \mathrm{C}$ requires a paradigm shift on the part of customers. The concept of the burden-free circular economy will only work if customers comply by returning and recycling the products, which will be a great challenge in many parts of the world.

\section{Product-Service Systems}

The concept of Product-Service Systems (PSS) leads into a very different direction. It has been intensively discussed in the literature since 1999, when Goedkoop et al. presented the idea for the first 
time. It shifts the focus from products to combining products with services, thereby contributing to the dematerialization of the offer (UNEP, 2003). The basic idea of dematerialization is that those products have the best environmental performance, which are not produced in the first place. The end point of this line of thought is dematerialization, where customer needs can be satisfied through services, without the need for a physical product. This product sustainability approach is in line with larger societal changes concerning the transformation from industrial economies to service economies and the increasing popularity of a sharing economy. Baines et al. (2007) provide the following definition in their widely cited review: "A PSS is an integrated product and service offering that delivers value in use. A PSS offers the opportunity to decouple economic success from material consumption and hence reduce the environmental impact of economic activity." ISO also promotes a shift from selling goods to offering services (ISO TR 14062).

PSS can be understood as a radical type of D4S (Tischner et al., 2009). Usually, the negative environmental impact of goods results to a large part from its need for physical inputs and the processing of those. Therefore, striving for gradual dematerialization can be one possibility to create more sustainable products. The underlying idea is to move value propositions towards dematerialization, i.e. the focus is no longer on selling the maximum quantity of physical items, but to fulfill customer needs through services, where appropriate in combination with the use of a material product. By offering a PSS the company provides a certain utility to the customer, rather than the ownership of a physical object. In this way, PSS may contribute to increased sustainability, as the demands of the customer may be fulfilled with a reduced environmental impact. Although PSS are not per se more sustainable than traditional approaches, their sustainability potential - particularly in environmental terms - is enormous. UNEP, therefore, sees PSS as a business strategy that is promising in terms of a triple win situation for the producer, the customer, and the environment (UNEP, 2003).

In general, three approaches to PSS can be distinguished: (1) services providing added value to the product life cycle, (2) services providing "final results" for customers, or (3) services providing "enabling platforms" for customers (UNEP, 2003). In the first case, companies provide additional services along with the classical product. The product is still sold to the customer, but offered in a package with i.e. maintenance, repair, up-grading or substitution services over a specific time period. In this case, the physical product is not changed and the environmental product life cycle performance is only marginally improved. In the second case, the company remains owner of the product, but satisfies the needs of the customer through a specific mix of services. An example is the purchase of pest control services in agriculture, which substitute the purchase of agrochemicals by the provision of a service to take care of occurring pests. In the third case, the customer rents or leases the product and pays only for the time he uses the device. As the producer remains owner of the physical product, this type of PSS should induce companies to invest in the durability, efficiency and reparability of their physical offerings. The extended lifespan and the collective use of one physical item by several customers may greatly reduce environmental burdens through a reduced amount of manufactured products. Benefits may not only occur in terms of environmental sustainability, decreased resource dependencies and reduced energy consumption, but also in terms of new market development, increased flexibility, more intense client relationships, an improved corporate identity, and an improved market and strategic 
position. PSS may foster the shift towards a service economy, a reduced customer focus on product ownership and a higher acceptance of dematerialized consumption (UNEP, 2003).

Introducing a PSS demands a new way of thinking of companies, as it requires a new way of interacting with customers and perhaps with complementary companies (UNEP, 2003). The focus is extended not just across the entire life cycle of the product, but also from the own product to a network of auxiliary products and service providers. The idea of PSS is also linked to a shift in perception of wellbeing from the dominant "product-based wellbeing", where a sense of wellbeing is derived from product ownership, to "access-based wellbeing", where it is derived from access to the service or the experience a good provides (Manzini, 2002). This requires not only design improvements and innovations, but also a close cooperation with customers. Hence PSS can become also a driver of social change (Crul and Diehl, 2009). This may be seen as a far-reaching contribution, to decouple well-being from consumption and particularly to decouple value creation from environmental consumption. The secondary effect of PSS is to foster a less material intensive lifestyle and society, which is very interesting for industrialized countries, but also bears great potential for developing countries (Tischner et al., 2009).

The concept of PSS primarily focuses on environmental issues and has a focus on resource efficiency and the limited use of non-renewable resources. Although PSS might have a positive societal effect, e.g. higher inclusion and accessibility by reduced usage costs and increased social cohesion in industrialized countries through the cooperative sharing of an item, social aspects along the value chain are typically excluded. In many of today's PSS, the producer introduces rental and leasing schemes, in which several consumers share one item. However, this development happens mostly detached from life cycle improvements. Products offered in sharing or pooling schemes mostly are negligent of material use, product design, or resource efficiency. Car-sharing providers, for instance, not necessarily start a continuous improvement process to make their car pool as sustainable as possible. Rather, they simply use their regular car types in a pooling scheme. In that case, a PSS should be seen much rather as a business model innovation, not as a product innovation (Tischner et al., 2009). Also rebound effects may occur as sharing an item typically requires less investment by customers than purchasing the item. These savings may be reinvested in other physical products with adverse effects on the environment.

\subsection{From better products to good products: Upcycle, Handprinting and Net Positive}

While the approaches to product sustainability discussed so far have had a clear focus on minimizing the negative impacts of products, a new generation of authors and institutions bring in a different focus on positive impacts of products. While negative impacts are to be minimized, positive impacts of products can and should be maximized. And, overall, the contribution of the product should be "net positive", which means the products should be giving back more to society and nature than they are taking. The ambition is no longer to simply get to "better products", but to aim for "good products". These approaches are presented under the labels of "Upcycle", "Handprinting" and "Net Positive". 


\section{Upcycle}

The "Upcycle" was presented by McDonough and Braungart in their 2013 book of the same title. They criticise traditional thinking about product sustainability, including their own $\mathrm{C} 2 \mathrm{C}$ work, as "basically making a suboptimal system more efficient by curtailing how much "bad" it produces: not doing the right things, but doing the wrong things better" (McDonough and Braungart, 2013). For them this is insufficient as a strategy because it encourages us to stick with what is poorly designed by being simply told to try to do less of it. But making it less bad simply is not good enough. We need to find ways to make it overtly good. They therefore ask for "no more zero".

They contrast the way business people think and the way environmentalists think. While a manager prefers seeing an upward-climbing line and wants increase and growth in production, sales and profits, much of the environmental work prefers a different chart, one inclined toward lower $\mathrm{CO} 2$ emissions, decreasing energy use, decreasing population growth, fewer cubic tons of pollutants. They suggest to combine these two different charts in one single chart and present their upcycle chart (Figure 4).

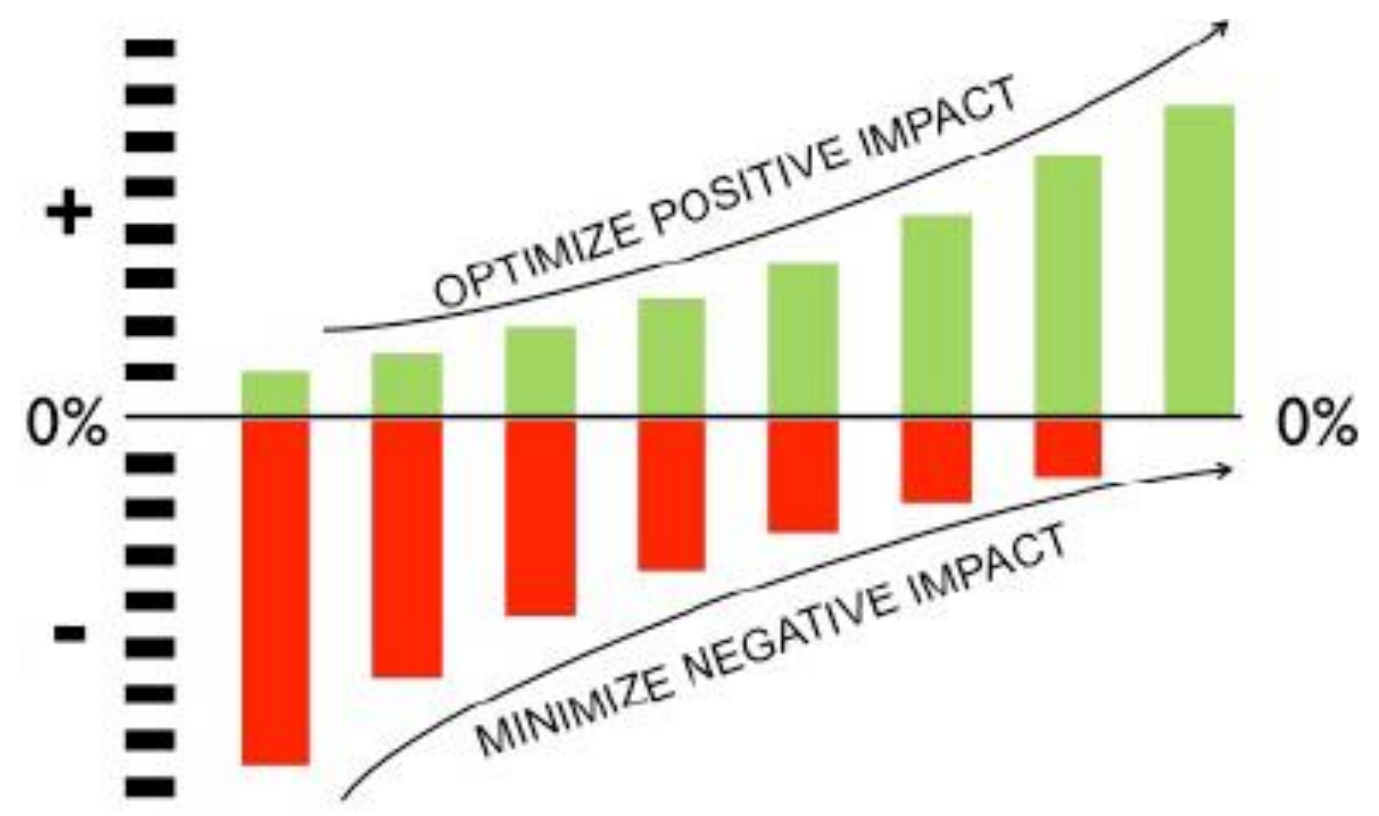

Figure 4: The Upcycle Chart (McDonough \& Braungart, http://mbdc.com/c2c-framework/)

While the lower side of the zero axis represents the traditional footprint logic striving to minimize negative impact ("less bad"), the top side is the upcycle, striving to optimize positive impact ("more good"). McDonough and Braungart (2013) propose that the desire to head to zero becomes not a culminating point but a midpoint. With reference to the example of workplace accidents, they prefer the ascending diagonal line to start below the zero and climb "happily" up to zero accidents, but then push further up toward better health for the employees, or for the workplace, or even for the community in which the company does business. This way you could go from an unhealthy workplace to one that does no harm, but then go on to a health-producing workplace. Designers and businesses need to think of where and how they can devise moments of upcycle that improve employee life, produce more solar energy per hour or more water purified during a manufacturing process. How this is done and how the 
creativity needed can be better supported by strategies and tools, unfortunately is not well developed by the authors.

\section{Handprinting}

The same idea as the upcycle has been presented lately by different authors using the term "handprinting". Dixon and Blackburn define the environmental handprint as "the good we do for the environment" (2013). It is a reverse logic compared to the footprint thinking. While reducing a footprint towards zero gets increasingly difficult - and in most cases of physical products even impossible increasing a positive handprint may resemble a perpetuum mobile. Instead of working towards a "neutral impact" product, certain unavoidable interferences with the environment are accepted, but counterbalanced by positive actions. They highlight the unlimited potential of handprinting as positive impacts sustain themselves as long as the product is produced or used and may accumulate over time (Dixon and Blackburn, 2013).

Several parties independently started developing handprinting concepts during the past years. The common agreement was that the exclusive focus on negative impacts of footprint concepts was too narrow and discouraging due to its negative terminology. One of the most popular supporters of handprint thinking is the Centre for Environmental Education (CEE) in India, which proposed the handprint as a symbol of environmental and social action in 2007 at the $4^{\text {th }}$ UNESCO International Conference on Environmental Education (Dixon and Blackburn, 2013). Another important contributor to handprint thinking and acting is the International Living Future Institute (ILFI) based in the USA. They not only refined and enlarged the concept, but they also launched a certification scheme - the "Living Product Challenge" (LPC) - and diverse handprinting tools (guidelines, databases, handprint calculator). However, for them LPC is a philosophy first, an advocacy tool second and a certification program third. Within their larger framework they go much further and include also Living Buildings, Living Communities and Living Food Systems (ILFI, 2015a).

For ILFI a footprint is what you "take" from the world, while a handprint is what you "give" to the world. And this is specifically how you change the world for the better and how you bring positive impacts. More precisely: "Handprints measure the positive that a product causes across its life cycle, such as harvesting more water and generating more energy than was required to make it" (ILFI, 2015a). In contrast to the footprint, which accounts for all negative impacts, the handprint sums up all beneficial environmental and social impacts. And: "While a product can never have a zero footprint, it can still be net positive if its handprint is bigger than its footprint" (ILFI, 2015a). Conceptionally, net positive (or net negative) is the difference between what products give to the world and what they take from the world. Companies are asked to make positive contributions through their products and along the product life cycles while simultaneously shrinking their negative footprints. Taking a production process for example, action based on a footprint logic would try to continuously reduce the amount of released waste water per product produced. A handprint logic would simultaneously search for possibilities to release the water to the environment cleaner than it was before. Change in the ILFI concept occurs relative to a baseline, which is usually the current or dominant product version, but a net positive product 
does also stand for itself. But how do we measure the change? There are no simple answers available yet. Different one-dimensional indicators such as carbon, eco-toxicity, human health impacts, safety, employee well-being, etc. can be used to make overall quantifications or comparisons. Using multidimensional indicators still is dependent on qualitative expert evaluations.

In their certification scheme ILFI calls on manufacturers to walk the talk of restorative sustainability by making their own operations net positive. As most of the product footprint occurs upstream of the product manufacturers, through supply chains of energy and raw materials, or downstream during the use phase, they have to go beyond their own operations and strive to make their supply chains and product life cycles net positive as well. And achieving life cycle net positive requires the creation of handprints (ILFI, 2015a). The certification standard includes 7 broad dimensions and 20 more specific imperatives (Table 1).

\begin{tabular}{|c|c|}
\hline Dimensions & Imperatives \\
\hline \multirow[t]{2}{*}{ Place } & 1 Responsible Place and Habitat Impacts \\
\hline & 2 Habitat Exchange \\
\hline Water & 3 Net Positive Water \\
\hline Energy & 4 Net Positive Energy \\
\hline \multirow[t]{2}{*}{ Health \& Happiness } & 5 Net Positive Material Health \\
\hline & 6 Human Thriving \\
\hline \multirow[t]{7}{*}{ Materials } & 7 Red List \\
\hline & 8 Living Economy Sourcing \\
\hline & 9 Responsible Industry \\
\hline & 10 Net Positive Climate \\
\hline & 11 Net Positive Waste \\
\hline & 12 Product Fit To Use \\
\hline & 13 Useful Life Disposal \\
\hline \multirow[t]{4}{*}{ Equity } & 14 Equitable Product Access \\
\hline & 15 Responsible Co-Products \\
\hline & 16 Equitable Investment \\
\hline & 17 Just Organizations \\
\hline \multirow[t]{3}{*}{ Beauty } & 18 Positive Handprinting \\
\hline & 19 Beauty and Spirit \\
\hline & 20 Inspiration and Education \\
\hline
\end{tabular}

Table 1: The 20 Imperatives of the Living Product Challenge (in bold print = core imperatives; in italics = handprinting imperatives) (ILFI, 2015b, 17)

Among the 20 imperatives ILFI considers 4 of them as "core imperatives" - net positive material health, red list, responsible industry, inspiration and education. And they consider 5 imperatives as particularly important for handprinting. Their "handprinting imperatives" are: net positive water, net positive energy, net positive material health, net positive climate and positive handprinting. They develop in more detail 
the requirements for handprinting in their Handprinting Guide (ILFI, 2015a). To give a feeling of how they evaluate the more uncommon imperatives of their challenge, they define the "beauty and spirit" imperative as demanding that "the product must be artfully designed and pleasing to use". Or they demand for their "inspiration and education" imperative that educational materials about the product must be provided to the public and that there must be an ongoing training program to educate workers. ILFI offers different certification options that are more or less demanding with regard to the handprinting performance.

The handprinting concept encourages fundamental change and promotes a different mindset that could have a big impact on environment and society. It promotes thinking and action for positive product impacts and striving towards net positive contributions. It highlights the importance of the precautionary principle and of transparency. It promotes decentralized production, close to where the products are sold to avoid long-distance transports. And a key principle lies in sharing innovations and exchanging ideas along the supply chain, within the industry and across industries in order to achieve the highest positive contribution. Sharing sustainable innovations along the supply chains, with competitors or even society at large increases the positive impact of a product. Also engaging with customers to encourage a more sustainable use of the product is a real handprinting opportunity (ILFI, 2015a). It is about enabling others to also positively contribute to sustainable development and inspires innovations that spread across companies and industries, thereby leveraging the collective impact.

ILFI realizes that companies might find it difficult to achieve substantial handprints at a product level. Their Living Products concept requires fundamental changes, which are currently rarely seen in manufacturing industries. Due to the novelty of the perspective, methods for implementation and accounting are still being developed. In reality companies will start with individual aspects and try to create handprints in specific categories. Or companies might choose to focus on handprints in the social dimension, where companies typically pursue positive goals, e.g. concerning the health or education of their employees or the granting of worker rights. Overall, it may be easier to switch from „doing less bad" to „doing maximum good" in the social and economic dimensions. Positive impacts are possible through providing employment, insurance, training opportunities for workers, stimulating the local economy, contributing to health and safety, or improving the literacy rate.

\section{Net Positive}

ILFI already incorporated net positive thinking into its Living Product guideline, by asking companies to go beyond generating handprints and ultimately aiming for net positive contributions. This is the explicit focus of the Net Positive concept as developed by Forum for the Future, WWF-UK and The Climate Group (2014). It demands positive impacts that outweigh negative impacts. This can be done by reducing harmful impacts and by creating positive impacts, which can and should be done simultaneously. Net positive is achieved when the negative impacts are overcompensated by the positive impacts. The net positive concept builds on the idea of regenerative or restorative sustainability, as it is used in the building sector (Robinson and Cole, 2015; Cole, 2012a and 2012b). The concept has been developed as a guidance for corporations as a whole: "In its broadest sense 'Net Positive' simply means 
putting more back into the environment or society than a company takes out, with a resulting positive corporate footprint" (Forum for the Future et al., 2014). But the concept has clear consequences for achieving net positive product footprints as well.

The net positive concept addresses the challenge to generate value not just for direct customers, but for society in general. As an explanation Forum for the Future et al. (2014) clarify different product impacts and they develop net positive principles. They distinguish between three different impacts that companies may have through their products or services: direct impacts, indirect impacts and impacts enabled through customers (Forum for the Future et al., 2014). While the first two types are well known already, the third type is new, interesting, but also challenging, because customers' behavior cannot be easily controlled by the company. For example, $8 \%$ of British Telecom's (BT) full carbon emissions are caused by its own operations, $64 \%$ by its supply chain and $28 \%$ by customers using their products. As part of their "Net Good" strategy their goal is to help BT's customers to reduce their carbon emissions by at least three times BT's own footprint by 2020. In 2013 both emissions were roughly equal. In order to reduce their direct and indirect impacts, they adopt sustainable design principles in product development and spread the message to their suppliers through the BT Better Future Supplier Forum. But they go beyond that and enable their customers to reduce their carbon emissions through smart systems that manage resources across entire cities, videoconferencing that helps avoid air travel, or communications technology that helps society make better use of the planet's resources (Forum for the Future et al., 2014).

Swedish furniture giant IKEA has set itself net positive targets and has made net positive the overarching principle of their sustainability strategy. For example, IKEA wants to become a net positive exporter of renewable energy by 2020 (IKEA, 2014). Kingfisher, a major European home improvement retailer, has formulated a vision and several targets aiming at a positive sustainability impact. They aim to have a "positive impact on people and communities, be restorative to the environment, become carbon positive, waste nothing and create wealth" (Kingfisher, 2016, p. 12). And Nespresso has introduced "the positive cup" as their overarching commitment for 2020 by stating: "At Nespresso, we believe that each cup of coffee can not only deliver a moment of pleasure, but also restore, replenish and revive environmental resources and communities. The Positive Cup's overall vision is to create a cup of coffee that has a positive impact on the world." (Nespresso, 2016) How this overall impact will be measured, however, has not been disclosed yet by Nespresso. 
In order to frame and explain the net positive approach, Forum for the Future et. al. suggest 12 principles (Table 2).

1. The organization aims to make a positive impact in its key material areas.

2. The positive impact is clearly demonstrable if not measurable.

3. As well as aiming to have a positive impact in its key material areas, the organization also shows best practice in corporate responsibility and sustainability across the spectrum of social, environmental and economic impact areas, in line with globally accepted standards.

4. The organization invests in innovation in products and services, enters new markets, works across the value chain, and in some cases, challenges the very business model it relies on.

5. A net positive impact often requires a big shift in approach and outcomes, and cannot be achieved by business-as-usual.

6. Reporting on progress is transparent, consistent, authentic and independently verified where possible. Boundaries and scope are clearly defined and take account of both positive and negative impacts. Any trade-offs are explained.

7. Net positive is delivered in a robust way and no aspect of a net positive approach compensates for unacceptable or irreplaceable natural losses, or ill treatment of individuals and communities.

8. Organizations enter into wider partnerships and networks to create bigger positive impacts.

9. Every opportunity is used to deliver positive impacts across value chains, sectors, systems, and throughput to the natural world and society.

10. Organizations publicly engage in influencing policy for positive change.

11. Where key material areas are ecological, robust environmentally restorative and socially inclusive methods are applied.

12.An inclusive approach is adopted at every opportunity, ensuring affected communities are involved in the process of creating positive social and/or environmental impacts.

Table 2: Principles of a net positive approach (Forum for the Future et al., 2014, 9)

Adopting a net positive approach demonstrates leadership and commitment to enhancing natural and social capital. The principles ask for making a demonstrable if not measurable positive impact in key material areas. And they point out that positive social impacts are focused on inclusiveness while ecological impacts are focused on restoration. Cooperation and partnerships should be fostered in order to leverage the positive impact. And public commitment and lobbying for sustainable change are also aspects of the Net Positive approach. Thereby, the ambition levels of net positive are much higher than those of established product sustainability tools and concepts. It fosters system thinking, beyond direct impacts of business operations, and challenges companies to understand the role of their business activities and their products in the wider system.

\subsection{An emerging model of True Product Sustainability: From Customer Value to Public Value}

A final phase in the evolution of PS models is reached with a changing focus from customer value to societal or public value. While the early concepts were addressing a range of negative product impacts with the aim to find ways to reduce these (negative) footprints, only recently newer concepts started to discuss positive product impacts. The ambition and goal progressed from product handprinting to becoming overall net positive, thereby moving on from making better products to making good products. A final phase in this evolution is reached with a shift in focus from generating product value for the consumers alone to also contributing value to society. A non-directed and often incidental contribution 
to society through net positive products is being replaced by a more directed and deliberate contribution to solving relevant societal issues. This is what we would qualify as "true product sustainability".

Different authors have addressed the idea of creating public value through products. The idea that products can positively contribute to the solution of sustainability challenges has been presented as early as 1992 when Ryan et al. (1992) coined the term "ameliorative product" and described products that help to solve current sustainability challenges. Wever et al. define an ameliorative product as "a product (or service) that is aimed at reducing an existing social and/or environmental problem that is not caused by the product's life cycle itself but rather helps in dealing with a problem that was already there" (2008). Examples include grey water systems for flushing the toilet, a floating device for quick containment of oil spills, or a straw that allows people to drink from contaminated water. Due to the product's purpose, aimed at improving or solving a sustainability challenge, they call these products "sustainable-function products". Similarly, Peattie (1995) distinguishes between "relative green" products and "absolute green" products. Relative green products reduce the negative environmental impacts caused in their own product life cycle, while absolute green products actually contribute to the improvement of the environment beyond the problems caused across the own product life cycle.

The concept of products contributing to the solution of sustainability problems is similar to what Griesshammer et al. (2007) define as "public value". They distinguish between three different types of product utility or value: practical utility, symbolic utility, and societal utility (public value). Practical utility represents the core function of the product and usually is the key requirement for a customer to purchase the product. Symbolic utility is also called added value or psychological utility. Symbolic utility is responsible for feelings like prestige, sense of identity or belonging to a group. In affluent societies, the practical utility is often taken for granted and the symbolic utility becomes a main decision criteria for purchase. The third utility, public value, refers to the impact of a product on society and environment. Ideally, the public value of a product contributes to the solution of global challenges like the reduction of poverty, climate protection, peacekeeping, the protection of biodiversity, creation of qualified jobs, or social stability (Griesshammer et al., 2007). Product design should consider all three types of utility.

Public value contributions of products can take different forms. First, there are products with a public value. Let's think of car sharing as a growing business segment and as an element in a more diverse intermodal mobility split. These services do not just cater to the mobility needs of young urban customers, who prefer the independence, the flexibility and the lower costs of having access to different kinds of mobility services, but they have significant environmental benefits as well. They reduce $\mathrm{CO} 2$ emissions and overall distances travelled on already highly congested roads. Second, there are products for a public value, if you think of IKEA as an example. It used its core competencies to develop emergency housing for natural disaster victims and refugees in collaboration with the United Nations High Commissioner for Refugees. These houses can be easily transported and set up to provide immediate shelter for those in need. They are already used in Iraq, Ethiopia and Syria and are welcomed by western nations to provide shelter for refugees. Another example may be US chemical giant Dow, who introduced their 2025 sustainability goals by stating: "We are proud to say that we have long been - and remain - committed to applying our science and engineering expertise to create sustainable 
solutions to some of the world's greatest challenges. We are continuing to reduce our own footprint; deliver ever-increasing value to customers and society through our handprint of products and solutions; and lead in developing a blueprint for a sustainable planet and society." (Dow, 2016) Third, there are also unethical products or services that should be produced less or not at all, because they are considered unacceptable from a public values perspective. Typically companies producing weapons or alcohol are excluded from responsible investments for these reasons. Furs, animal testing and cruel practices with animals in general are considered unacceptable in Western countries. Many more products and services are considered to be controversial in different cultural contexts. Also their assessments are dynamic and changing, if you think of the escalating risks concerning products such as of fast food, soft drinks, meat, the privatization of water sources for commercial exploitation, fast fashion, or SUVs.

Meynhardt and Bartholomes (2011) predict that products - and companies - will be assessed more for their public value contribution in the future. A Nielsen global survey on "The sustainability imperative" presents supporting data for consumer brands. They found that in 2014 alone, sales of consumer goods from brands with a demonstrated commitment to sustainability have grown more than $4 \%$ globally, while those without grew less than $1 \%$. They found that overall the number of consumers willing to pay more for brands committed to a positive social and environmental impact continues to rise, reaching $66 \%$ in 2015. And these results are very robust across age groups, income groups and different countries. It is true in particular for "Generation Z", with nearly three out of four consumers ages 34 and under willing to pay more. Surprisingly, it is true for consumers earning less than $\$ 20,000$, who were even found to be 5\% more willing to pay more than those with incomes greater than $\$ 50,000$ (68\% vs. 63\%). And it was found to be true for consumers from less developed markets as well. For $62 \%$ of the 30,000 consumers polled, brand trust tops the list of factors that influence consumer purchasing. They suggest brands to increase their trust by demonstrating commitment to social and environmental sustainability, which is even more important for consumers who are willing to pay more (Nielsen Company, 2015).

\section{$4 \quad$ Summary and conclusions}

A company's products are important levers not just for improving business sustainability but also for sustainable development. Although many businesses have started to critically assess their products in terms of ecological and social performance, there is much room for improving their sustainability performance as we have shown in this paper. In order to contribute to sustainable development, most product sustainability approaches discussed and applied today are not sufficient. A product demonstrating some incremental ecological or social improvements does not deserve the designation "sustainable". Truly Sustainable Products need to be holistically improved, net positive and - more than anything else - aligned with the sustainability challenges we are collectively facing.

In looking back at the evolving perspectives of product sustainability presented in section 3 , we can group the different concepts into three very different phases that have emerged over time and that are moving towards True Product Sustainability (Table 3): 


\begin{tabular}{|c|c|c|}
\hline Old Model („From“) & New concept & New Model („To“) \\
\hline Selective Improvements & $\Longrightarrow$ & Holistic Improvements \\
\hline Production centered & Eco-Design & Product life-cycle \\
\hline Environmental focus & Design for Sustainability & Sustainability focus \\
\hline $\begin{array}{c}\text { Linear process (Cradle-to- } \\
\text { Grave) }\end{array}$ & Cradle-to-Cradle & Closed loop \\
\hline Material efficiency & Product Service System & Dematerialization \\
\hline Better Products & $\Longrightarrow$ & Good Products \\
\hline $\begin{array}{c}\text { Reducing footprint (minimize } \\
\text { negative impact) }\end{array}$ & Upcycle \& Handprinting & $\begin{array}{c}\text { Increasing handprint } \\
\text { (optimize positive impact) }\end{array}$ \\
\hline Relative improvements & Net Positive & Absolute improvements \\
\hline Private Value & & Public Value \\
\hline Benefits to the customer & $\begin{array}{l}\text { Contributing to solving } \\
\text { societal problems }\end{array}$ & Benefits to society \\
\hline
\end{tabular}

Table 3: Phases in the development of product sustainability concepts toward "True Product Sustainability"

In Phase 1 product sustainability is moving from selective to holistic improvements. The holistic character reflects in a move from production to the whole product life-cycle, a widening of the environmental to a three-dimensional sustainability focus, a move from a linear cradle-to-grave model to a circular closed loop model, and in a move from a focus on material efficiency to a focus on product dematerialization. At the end of Phase 1 a sustainable product integrates the triple bottom line of sustainability and considers economic, ecological and social impacts. A holistic approach demands the inclusion of all relevant sustainability aspects and avoids the problem of burden shifting. It includes a deliberate attempt to close the material loops and to look for possibilities to dematerialize the product offer as much as possible. As a consequence, incremental product improvements and cherry-picking on the part of the product designers cannot be seen as adequate any more. They are required to apply a holistic and inclusive perspective, if their products should qualify as (more) sustainable products.

In Phase 2 product sustainability is moving from better products to good products. Reducing the product footprint, thereby minimizing its negative impact is not good enough anymore. Products need to increase also their handprint, thereby optimizing their positive impact on the environment and society. Also, relative improvements are not sufficient any more if they are supposed to be good products. Designers need to strive for absolute improvements in their products with regard to their sustainability performance. This means, companies have to work towards solutions that do not just perform better, but that are actually unobjectionable. It demands solutions that are not simply better compared to alternatives, but that don't pose relevant risks for the environment or society. Only materials and technologies are used with low or no risks for society and the environment (precautionary principle). It has become clear by now, that product sustainability is not only about the avoidance of harm, but it is about striving to be a source of positive change. Opportunities to create positive change exist along the existing product life cycle and products should thus be primarily designed to tackle those issues that arise within their own product life cycles. But opportunities exist as well beyond their own product life cycles. 
In Phase 3 product sustainability is moving from private value to public value, from products that benefit their customers to products that benefit society equally. This is the highest level of sustainable value creation, where products instead of using or destroying ecological and social capital create value on various levels. Sustainable products do not only have positive effects on the immediate environment and the people directly involved in the product life cycle (e.g. suppliers, workers, customers), but they also account for indirect product life cycle impacts on society and eco-systems. They contribute to external sustainability challenges and seek ways to positively enhance the environment and social wellbeing. Thereby, the contribution to public value creation might result from the primary product purpose - e.g. products for the bottom-of-the-pyramid or ameliorative products - or from an enhancement of the product life cycle through positive handprints. On this highest level of product sustainability the product should not only be net positive, but it should be also directed towards the creation of societal value. Thus these products may be called "truly sustainable", because they make a net positive contribution and contribute to solving sustainability problems we are collectively facing.

Our paper provides a new and more ambitious meaning of what a "sustainable product" is and what it should be. In order to get there, we have analyzed and characterized the evolving concepts of product sustainability and clarified their specific sustainability contributions. We have synthesized the conceptual evolution into three major phases which move the understanding of product sustainability significantly and raise the level of ambition. Truly sustainable products are products that are valuable for society and the planet. In developing our product sustainability typology, we aim to refine the understanding of what is a "sustainable product" and to provide orientation for all parties interested in developing products with a real impact on sustainable development. Our typology provides a framework for characterizing products as truly sustainable and for inspiring companies to aim for higher sustainability levels.

Critics may call this unrealistic. And indeed, there are many practical obstacles on this journey that we have not looked at in this paper, as its ambition is mainly conceptual. We do think, however, that by developing a product sustainability typology and by showing the way towards true product sustainability we can make a relevant contribution to thinking about product sustainability. Relevant changes usually start in our heads and are guided by our explicit and implicit frames of mind. If companies, consumers and researchers think about product sustainability in terms of Product Sustainability 1.0, as most of them still do, they will neither address nor be aware of higher levels of product sustainability. By showing the way to higher order levels of achievement, we help to focus our mind on Product Sustainability 2.0 and ultimately Product Sustainability 3.0. This may very well release the energy and creativity that is needed to realize more ambitious solutions.

A major mental obstacle in moving to higher and more ambitious levels of sustainability very often is the traditional trade-off model, as used in business and grounded in economic thinking. This model insists that you can either have more economic performance or more societal value, more private value or more public value, but not both. It assumes a law-like trade-off between competing goals forcing you to make a hard choice. However, it may well be exactly this mental model that is more in the heads and less in real life that acts like a mental block, as has been suggested by Jay et al. (2015). Companies like Nike with their Flyknit sports shoe line learned that they had to tackle everything at 
once, increased customer value by increasing comfort and running performance, increased business value by cutting production time and costs and increased social value by reducing landfill waste and the need for labor-intensive, low wage work. And they succeeded with their sustainability-oriented product innovation by holding firm to its commitment to both, economic performance and societal impact. Instead of moving along the trade-off line they deliberately went after expanding the existing frontier and pushing their limits further out. It lead them to an entirely new way of producing athletic footwear. Unilever, has been pursuing an equally ambitious strategy on a company level with their sustainable living plan. Since its launch in 2010 they simultaneously pursue goals to reduce the environmental impact of their products, to improve the health and well-being of their customers, to enhance the livelihood of their smallholder suppliers while doubling their sales by 2020 . They try to achieve everything at the same time and they seem to be faring very well with their strategy that includes products, but goes well beyond them. It moves on from product development to strategy development and business model innovation, starting from on an outside-in perspective. (Unilever, 2017) By deliberately pursuing highly ambitious stretch goals, a lot of energy and creativity seems to be released inside the company that allows for much better solutions in very different dimensions.

How far reaching these individual projects, overarching visions and goals may be in the end is not clear yet. However, they signal clearly that the product sustainability evolution has reached the pioneering businesses and it has already started to influence them. A typology for product sustainability should be helpful in framing the discussions and in leading them forward. While early concepts of product sustainability were addressing negative product impacts with the aim to find ways to reduce their negative footprints, it is time to think seriously about positive product impacts with regard to the sustainability challenges we are collectively facing. This change in perspective definitely has the potential to inspire companies, developers and designers in creating positive product change and to start a positive momentum.

\author{
Abbreviation Index \\ BST business sustainability, related to the typology developed by Dyllick \& Muff (2016) \\ BT British Telecom \\ C2C cradle-to-cradle \\ CEE Centre for Environmental Education based in India \\ D4S design for sustainability \\ eLCA environmental life-cycle assessment \\ ILFI International Living Future Institute based in the USA \\ ISO International Standards Organization \\ LCC life cycle costing \\ LCSA life cycle sustainability assessment \\ LPC living product challenge, product certification scheme by ILFI \\ PEF product environmental footprint, concept launched by the European Commission \\ PS product sustainability \\ PSS product-service system(s)
}




$\begin{array}{ll}\text { PWC } & \text { PricewaterhouseCoopers } \\ \text { SAM } & \begin{array}{l}\text { Sustainable Asset Management, Swiss based investment company with a specific } \\ \text { focus on sustainability, owner of the Dow Jones Sustainability Indexes family }\end{array} \\ \text { SD } & \begin{array}{l}\text { sustainable development } \\ \text { SDGs }\end{array} \\ \text { U.N. Sustainable Development Goals } \\ \text { SME } & \text { social life-cycle assessment } \\ \text { SOI } & \text { small and medium Enterprise(s) } \\ \text { WBCSD } & \text { World Businability-oriented innovation }\end{array}$

\section{References}

Adams, R., Jeanrenaud, S., Bessant, J., Denyer, D. \& Overy, P., 2016. Sustainability-oriented Innovation: A Systematic Review. International Journal of Management Reviews 18, 180-205.

Adams, R., Jeanrenaud, S., Bessant, J., Denyer, D. \& Overy, P., 2012. Innovating for sustainability. A Guide for Executives. Prepared by the Network for Business Sustainability. http://nbs.net/wpcontent/uploads/NBS-Executive-Report-Innovation.pdf (accessed July 1, 2016)

Baines, T., Lightfoot, H., Evans, S., Neely, A., et al., 2007. State-of-the-art in product-service systems. Proc. Inst. Mech. Eng. J. Eng. Manuf. 221 (10), 1543-1552.

Belz, F.-M., Peattie, K., 2012. Sustainability marketing: A Global Perspective. Chichester: Wiley.

Boons, F., Montalvo, C., Quist, J., \& Wagner, M., 2013. Sustainable innovation, business models and economic performance: An overview. Journal of Cleaner Production 45, 1-8.

Bové, A.-T., Bonini, S., 2014. Sustainability's strategic worth. McKinsey global survey results. (http://www.mckinsey.com/insights/sustainability/sustainabilitys strategic worth mckinsey globa 1_survey_results) (accessed July 1, 2016)

Cole, R.J., 2012a. Regenerative design and development: Current theory and practice. Build. Res. Inf. 40 (1), 1-6.

Cole, R.J., 2012b. Transitioning from green to regenerative design. Build. Res. Inf. 40 (1), 39-53.

Cradle to Cradle Products innovation institute. 2013. Cradle to cradle certified product standard. Version 3.0. http://www.c2ccertified.org/images/uploads/C2CCertified_Product_Standard_V3.pdf (accessed July 12, 2016)

Crul, M., 2009. Introduction to the D4S. A step-by-step approach. In: Crul, M., Diehl, J.C., \& Ryan, C. (2009). Design for sustainability - A step-by-step approach. UNEP, Paris, 15-22.

Crul, M., Diehl, J.C., 2009. Out-of-the-box. Radical sustainable product innovation. In: Crul, M., Diehl, J.C., Ryan, C., 2009. Design for sustainability - A step-by-step approach. UNEP, Paris, 75-82.

Crul, M., Diehl, J.C., Ryan, C., 2009. Design for sustainability - A step-by-step approach. UNEP, Paris.

De Simone, L., Popoff, F. (Eds), 2000. Eco-efficiency: The business link to sustainable development. Cambridge, MA: MIT Press.

Dixon, W., Blackburn, N., 2013. Our environmental handprint - The good we do. Presented at the 2013 IEEE Conference on Technologies for Sustainability, Portland, USA. 01 Aug - 02 Aug 2013. 
Doherty, B.; Haugh, H.; Lyon, F., 2014. Social enterprises as hybrid organizations: a review and research agenda. International Journal of Management Reviews 16, 417-436.

Dow, 2016. http://www.dow.com/en-us/science-and-sustainability/2025-sustainability-goals (accessed November 3, 2016)

Dyllick, T., Hockerts, K., 2002. Beyond the business case for corporate sustainability. Business Strategy and the Environment 11 (2), 130-141.

Dyllick, T., Muff, K., 2016. Clarifying the meaning of sustainable business: Introducing a typology from business-as-usual to true sustainability. Organization \& Environment 29 (2), 156-174.

Edwards, S., 2009. A new way of thinking: The Lowell Center framework for sustainable products. http://www.sustainableproduction.org/downloads/LowellCenterFrameworkforSustainableProducts 11 -09.09.pdf. (Accessed 9 September 2014)

Ellen MacArthur Foundation, McKinsey, WEF, 2014. Towards the circular economy: Accelerating the scale-up across global supply chains. http://www3.weforum.org/docs/WEF_ENV_TowardsCircularEconomy_Report_2014.pdf (accessed 12 July, 2016)

EU Commission, 2015. Commission Recommendation of 2 December 2015 on "Closing the loop - An EU action plan for the circular economy". COM (2015) 614 final.

EU Commission, 2013. Commission Recommendation of 9 April 2013 on "Building the single market for green products". COM/2013/0196 final.

Fabrycky, W.J., Blanchard, B.S., 1991. Life cycle cost and economic analysis. Englewood Cliffs: Prentice Hall.

Fargnoli, M. De Minicis, M., Tronci, M., 2014. Design management for sustainability: An integrated approach for the development of sustainable products. Journal of Engineering and Technology Management 34, 29-45.

Fiksel, J., McDaniel, J., Spitzley, D., 1998. Measuring product sustainability. Journal of Sustainable Product Design 6, 7-19.

Forum for the Future, WWF, The Climate Group, 2014. Net positive - A new way of doing business. https://www.forumforthefuture.org/sites/default/files/Net\%20Positive\%20report.pdf (accessed 12 July, 2016)

Gattenby, D.A., Foo, G., 1990. Design for X: the key to competitive and profitable markets. AT\&T Technical Journal 69 (3), 2-13.

Grießhammer, R., Buchert, M., Gensch, C. O., et al., 2007. PROSA - Product sustainability assessment. Leitfaden.

Öko-Institut

(Ed.), http://www.prosa.org/fileadmin/user upload/pdf/leitfaden ENDVERSION.pdf (accessed 12 July, 2016)

Haanaes, K ., Reeves, M., von Strengvelken, I., et al., 2012. Sustainability nears a tipping point. MIT Sloan Management Review and BCG, Research Report, Winter, Boston.

Haanaes, K., Arthur, D., Balagopal, B., et al., 2011. Sustainability: The "embracers" seize advantage. MIT Sloan Management Review and BCG, Research Report, Winter, Boston.

Hansen, E. G., Grosse-Dunker, F., Reichwald, R., 2009. Sustainability innovation cube-a framework to evaluate sustainability-oriented innovations. International Journal of Innovation Management 13 (04), 683-713. 
IKEA, 2014. People \& Planet Positive. IKEA Group Sustainability Strategy for 2020. First published October 2012. Updated June 2014. http://www.ikea.com/ms/de_DE/pdf/reportsdownloads/sustainability-strategy-people-and-planet-positive.pdf (accessed 15 August, 2016)

ILFI, 2015a. Living product challenge 1.0 Guide: Handprinting. A visionary path to a regenerative future. Seattle, USA. https://living-future.org/sites/default/files/LPCGuideHandprinting final web.pdf (accessed 12 July, 2016)

ILFI, 2015b. Living Product Challenge 1.0 - A visionary path to a regenerative future. Seattle, USA. https://living-future.org/sites/default/files/LPC_Standard_web.pdf (accessed 12 July, 2016)

ISO TR 14062, 2002. Environmental management - Integrating environmental aspects into product design and development. Technical Report. Geneva.

ISO 14001, 2015: Environmental management systems. Requirements with guidance for use. Geneva.

ISO 14006, 2011. Environmental management systems - guidelines for incorporating ecodesign. Geneva.

ISO 14020, 2000. Environmental labels and declarations -- general principles. Geneva.

ISO 14040, 2006. Environmental management - life cycle assessment - Principles and framework. Geneva.

Jay, J., Gonzales, S., Swibel, M., 2015. Sustainability-oriented innovation: A bridge to breakthroughs. MIT Sloan Management Review, Big Idea: Sustainability, Blog, November 10.

Kingfisher, 2016. This is personal. Sustainability Report 2015/16. Delivering our strategy towards net positive.

https://www.kingfisher.com/sustainability/files/reports/cr_report_2016/2016_Sustainability_Report .pdf (accessed 15 August, 2016)

Klewitz, J., Hansen, E. G., 2014. Sustainability-oriented innovation of SMEs: a systematic review. Journal of Cleaner Production 65, 57-75.

Kiron, D., Kruschwitz, N., Haanaes, K., et al., 2013. The innovation bottom line. MIT Sloan Management Review and BCG, Research Report, Winter, Boston.

Linton, J.D., Klessen, R., Jayaraman, V., 2007. Sustainable supply chains: An introduction. Journal of Operations Management 25 (6), 1075-1082.

Manzini, E., 2002. Context-based wellbeing and the concept of regenerative solution: A conceptual framework for scenario building and sustainable solutions development. Journal of Sustainable Product Design 2, 141-148.

MBDC, 2013. Beyond sustainability. Cradle to cradle science, innovation and leadership. Publication of McDonough Braungart Design Chemistry, Virginia, USA.

McDonough, W. \& Braungart, M., 2002. Design for the triple top line: New tools for sustainable commerce. Corporate Environmental Strategy 9 (3), 251-258.

McDonough, W., Braungart, M., 2013. The upcycle: Beyond sustainability - designing for abundance. Melcher Media, New York, USA.

Millenium Ecosystem Assessment (MEA), 2005. Ecosystems and human well-being: Opportunities and challenges for industry. Washington D.C.: World Resources Institute.

Meynhardt, T., Bartholomes, S., 2011. (De)Composing public value: In search of basic dimensions and common ground. International Public Management Journal 14 (3), 284-308.

Mohrman, S.A., Worley, C.G., 2010. The organizational sustainability journey: introduction to the special issue. Organizational Dynamics 39, 289-294. 
Montiel, I., Delgado-Caballos, J., 2014. Defining and measuring corporate sustainability: Are we there yet? Organization \& Environment 27 (2), 113-139.

Network for Business Sustainability, 2012. Definition of business sustainability, http://nbs.net/about/what-is-business-sustainability/ (accessed 12 July, 2016)

Nespresso, 2016. https://www.nespresso.com/fr/en/developpement-durable (accessed 3 November, 2016)

Nielsen Company, 2015. The sustainability imperative. New insights on consumer expectations. http://www.nielsen.com/us/en/insights/reports/2015/the-sustainability-imperative.html (accessed 25 November, 2015)

Okongwu, U., Morimoto, R., Lauras, M., 2013. The maturity of supply chain sustainability disclosure from a continuous improvement perspective. International Journal of Productivity and Performance Management 62 (8), 827-855.

Ottman, J. A., Stafford, E. R., Hartman, C. L., 2006. Avoiding green marketing myopia: ways to improve consumer appeal for environmentally preferable products. Environment: Science and Policy for Sustainable Development 48 (5), 22-36.

Parent, J., Cucuzzella, C., Revéret, J.P., 2012. Revisiting the role of LCA and SLCA in the transition towards sustainable production and consumption. Int J Life Cycle Assess 18 (9), 1642-1652.

Peattie, K., 1995. Environmental marketing management: Meeting the green challenge. London: Pitman.

Porter, M.E., Kramer, M.R., 2011. Creating shared value. Harvard Business Review, 89 (1/2), 62-77.

Raworth, K., 2012: A safe and just space for humanity. Can we live within a doughnut? Oxfam Discussion Papers. https://www.oxfam.org/sites/www.oxfam.org/files/dp-a-safe-and-just-space-forhumanity-130212-en.pdf (accessed 12 July, 2016)

Rebitzer, G., Ekvall, T., Frischknecht, R., Hunkeler, D., Norris, G., Rydberg, T., Pennington, D. W., 2004. Life cycle assessment: Part 1: Framework, goal and scope definition, inventory analysis, and applications. Environment international 30 (5), 701-720.

Robinson, J., Cole, R. J., 2015. Theoretical underpinnings of regenerative sustainability. Building Research \& Information 43 (2), 133-143.

Rockström, J. et al., 2009. A safe operating space for humanity. Nature 461, 472-475.

Ryan, C.J., Hosken, M., \& Greene, D., 1992. EcoDesign: design and the response to the greening of international markets. Design Studies 13 (1), 3-22.

SAM Group, PricewaterhouseCoopers, 2006. The sustainability yearbook 2006. Zurich.

Schaltegger, S., Wagner, M., 2011. Sustainable entrepreneurship and sustainability innovation: categories and interactions. Business Strategy and the Environment 20 (4), 222-237.

Schaltegger, S., Wagner, M., Eds., 2006. Managing the business case for sustainability. Sheffield: Greenleaf Publishing.

Steffen, W. et al., 2015. Planetary boundaries: Guiding human development on a changing planet. Science. 347 (6223).

Steger, U., 2006. Building a business case for corporate sustainability. In: Schaltegger, S., Wagner, M. (Eds.). Managing the business case for sustainability. Sheffield: Greenleaf, 412-443.

Tischner, U., Ryan, C., Vezzoli, C., 2009. Product-Service Systems. In: UNEP (Ed.), 2009: Design for Sustainability - A step-by-step approach. Chapter 7. Publication of the United Nations Environment Programme and Delft University of Technology. 
Unilever, 2017. The Unilever Sustainable Living Plan. https://www.unilever.com/sustainableliving/the-sustainable-living-plan/. (accessed March 17, 2017)

United Nations General Assembly, 2015. Transforming our world: The 2030 agenda for sustainable development. Resolution adopted on 25 September 2015. A/RES/70/1. United Nations: New York 21 October 2015.

United Nations (SDKP). Sustainable development knowledge platform. https://sustainabledevelopment.un.org/topics/sustainableconsumptionandproduction (accessed July 12, 2016)

UNEP, 2003. Product-service systems and sustainability: Opportunities for sustainable solutions. http://www.unep.org/resourceefficiency/Portals/24147/scp/design/pdf/pss-imp-7.pdf (accessed 26 January, 2015).

UNEP, SETAC, 2007. Life cycle management. A business guide to sustainability. UNEP/SETAC Life Cycle Initiative. UNEP, Paris.

UN Global Compact, Accenture, 2013. The UN global compact - Accenture CEO study on sustainability 2013. Architects of a better world. https://www.unglobalcompact.org/docs/news events/8.1/UNGC Accenture CEO Study 2013.pdf (accessed 12 July, 2016)

UN Global Compact, Accenture, 2010. A new era for sustainability. The UN Global Compact Accenture CEO Study on Sustainability. https://www.unglobalcompact.org/library/230 (accessed 12 July, 2016)

Valdivia, S., Ugaya, C., Hildenbrand, J., Traverso, M., Mazijn, B., Sonnemann, G., 2013. A UNEP/SETAC approach towards a life cycle sustainability assessment - our contribution to Rio+20. International Journal of Life Cycle Assessment 18 (2013), 1673-1685.

World Business Council for Sustainable Development (WBCSD), 2008. Sustainable consumption facts and trends - From a business perspective. Geneva, Switzerland.

Wever, R., Boks, C. B., Bakker, C. A., 2008. Sustainability within product portfolio management. Sustainable Innovation 08 Conference, Malmö, Sweden. http://repository.tudelft.nl/islandora/object/uuid:563ad303-48d6-4376-99736ed358aeccb3?collection=research $($ accessed 12 July, 2016)

Whiteman, G., Walker, B., Perego, P.M., 2013. Planetary boundaries: Ecological foundations for corporate sustainability. Journal of Management Studies. 50 (2), 307-336.

World Economic Forum (WEF), Accenture, 2012, More with less: Scaling sustainable consumption and resource effciency. Geneva.

WWF, 2016. Living Planet Report 2016. Risk and resilience in a new era. WWF International: Gland, Switzerland. http://awsassets.panda.org/downloads/lpr_living_planet_report_2016.pdf (accessed 2 November, 2016)

Zamagni, A., Pesonen, H. L., Swarr, T., 2013. From LCA to life cycle sustainability assessment: concept, practice and future directions. The International Journal of Life Cycle Assessment 18 (9), $1637-1641$. 